日臨外会誌 48 ( 8 ), 1085-1089, 1987

原著

敗血症性ショックを併発した重症腹膜炎症例における 手術術式の検討

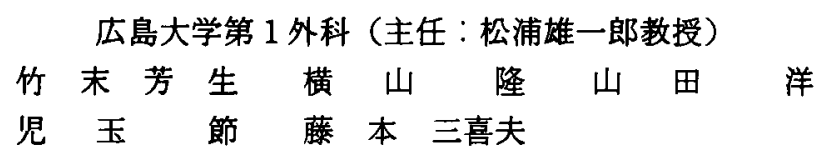

最近 3 年間に 6 例の敗血症性ショックを併発した重症腹膜炎症例に対し腸瘻造設によ る二期的手術を施行したので報告した。 その根拠として第一に, 腹腔内 endotoxin 投与 実験にて腸管の組織血流值を水素クリアランス法で測定したところ, 血殴が維持された

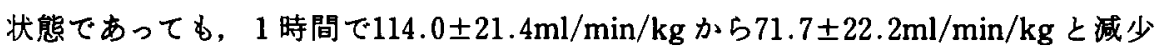
し，対照群と有意差を認めた $(p<0.05)$.この結果より endotoxin 血症時には縫合不全 の可能性が高いと考光た。第二に敗血症性ショック時においては, 血清 fibronectin 值や 補体 $\mathrm{C}_{3} \mathrm{c}$ は低値を示寸症例が多く，さらに手術侵襲が加わる事により减少を認め，この ような状態で䋖合不全が発生したら生体はすでに対処する力を有しておらす，致命的に なると考えた.ここで, 敗血症性ショック症例では, 腹腔内感染巣の完全なドレナージ を計る余り, 手術侵敬を過大とし, 術後患者の状態を悪化させる場合もあり，この点が 今後の課題と考えられた。

来引用語：敗血症性ショック, 腹膜炎, endotoxin 血症, 水素クリアランス法, 血清 fibronectin

はじめに

敗血症性ショックまで進行した重症腹膜炎症例では 繁急手術になる場合が多く，充分な術式についての検 討を行ら事は困難であり，術後合併症を起こして初め て術式の選択の誤りを感ずる事すあり，平時よりこの よ5な症例における手術方針を決めておく必要がある と考えられる。そこで我々は最近 3 年間に释験した敗 血症性ショックを起こした重症腹膜炎に対し, 後述す る点に留意して手術施行し，良好な治療成績が得られ たので，実験的検討ならびに若干の文献的考察を加衣 報告する。

\section{1. 症例ならひに成繒}

昭和59年 1 月から昭和61年10月までの約 3 年間に, 厇島大学第 1 外科教室において経験した重症腹膜炎症 例で来院時, 末梢循環不全や意識障害を呈した症例を 対象とした，表 1 に各症例の術前検查成績を示すか; 症例 6 を除く 5 例において, 黄疸, 䀥機能低下, 低酸 素血症，血小板减少等を認めており，多䁍器不全（以

昭和61年12月17日受付 62 年 6 月 2 日採用
下MOF)準備状態と考えられた. Endotoxin 血症も 6 例中 4 例認められた。 また穿孔後来院までの時間は 平均6.2日と長期間経過したものが多くみられた。手術 術式は二期的手術を原則とし，各症例について以下の 如く行なった。

症例 $1 ： 64$ 歳女性，放射性腸炎に上る回腸穿孔。穿 孔部を含めた回腸切除後両端を腸瘦とした。

症例 $2: 53$ 歳女性, 多発性動脈炎(以下 PN) による 小腸多発穿孔. 小腸広範囲切除後両端を腸瘦とした。 なお，機能的予後を考慮して残した小腸にも潰瘍病变 を認めた。

症例 3：48歳男性. 外鹪性横行結腸穿孔。横行結腸 壊死部切除後端々吻合, 上行結腸睢造設.

症例 $4: 45$ 歳男性. 虫垂炎及び大腸䄸室炎術後イレ ウスに対する手術に捛ける大腸の縫合不全. 結腸離開 部閉鎖, 回腸㾇造設.

症例 $5 ： 73$ 歳女性。直腸癌穿孔。Hartman 手術 (S 状結腸掼造設).

症例 $6: 50$ 瓷男性。特発性直腸穿孔. 穿孔部閉鎖, $\mathrm{S}$ 状結腸瘦造設 


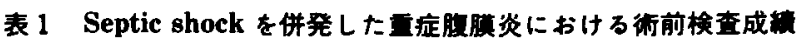

\begin{tabular}{|c|c|c|c|c|c|c|c|}
\hline Case & $\begin{array}{c}\text { TBil } \\
\text { (mg/dl) }\end{array}$ & $\begin{array}{c}\text { BUN } \\
(\mathrm{mg} / \mathrm{dl})\end{array}$ & $\begin{array}{c}\text { Creat } \\
(\mathrm{mg} / \mathrm{dl})\end{array}$ & $\begin{array}{c}\mathrm{PaO}_{2} \\
(\mathrm{mmHg})\end{array}$ & $\begin{array}{l}\mathrm{PaCO}_{2} \\
(\mathrm{mmHg})\end{array}$ & $\begin{array}{c}\text { 血小板 } \\
\left(\times 10^{4} \mathrm{~mm}^{3}\right)\end{array}$ & $\begin{array}{c}\text { Endotoxin } \\
\text { (定性) }\end{array}$ \\
\hline 1 & 3.2 & 36 & 0.9 & $108^{\circ}$ & 31 & 7.1 & $( \pm)$ \\
\hline 2 & 2.3 & 10 & 0.7 & 68 & 32 & 18.3 & $(-)$ \\
\hline 3 & 1.4 & 119 & 8.9 & 45 & 41 & 4.9 & $( \pm)$ \\
\hline 4 & 2.8 & 9 & 0.8 & 58 & 36 & 12.8 & $(+)$ \\
\hline 5 & 0.4 & 55 & 2.2 & 65 & 32 & 8.3 & $( \pm)$ \\
\hline 6 & 0.9 & 13 & 0.9 & 88 & 25 & 18.3 & $(-)$ \\
\hline
\end{tabular}

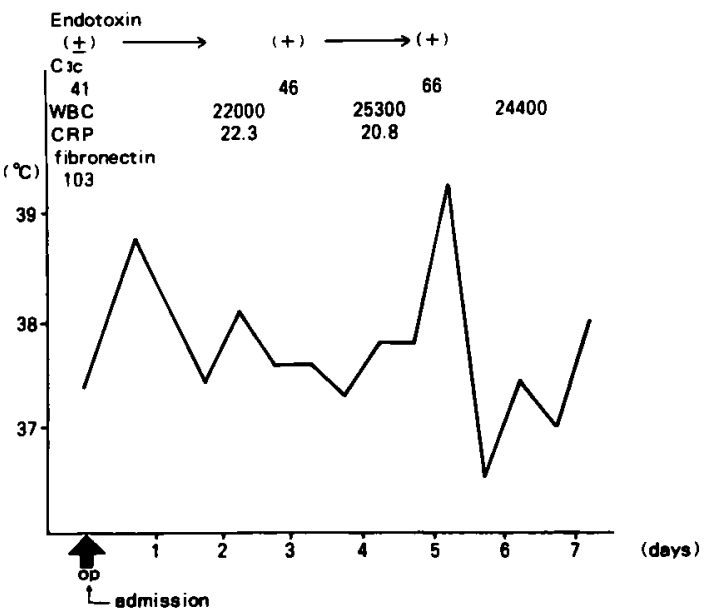

图 1 Case 64y. ㅇ Panperitonitis due to perforation of the ileum (post radiation ileitis)

以上の術式を行ったが, 術中出血量は平均 $916 \mathrm{ml}$, 手 術時間は平均 2 時間 6 分であり, poor risk の症例で あった事を考虑すれば手術德襲は大きいと考えられ た.

全症例㭪後感染のコントロールは可能であり，予後 は他病死による 1 例を除き全例生存中である.しかし， 1 例は術後の感染のコントロールに難沾したので，そ の経過を图1に示す。術前のリムルステストでは(士) であったがトトレナージ手術後りムルステスト（十） と endotoxin 血症の悪化を認めた.

\section{2. 重症腹膜资症例における血清 fibronectin 值の推移についての検討}

昭和55年以後の endotoxin 血症を呈した重症腹膜 炎症例における血清 fibronectin 値の推移についての 検討を行なった(図 2)。このような症例においてはす でに来院時より低値傾向を示す事が多く，さらに手術 侵巃が加わる事により减少を認めている。またドレ

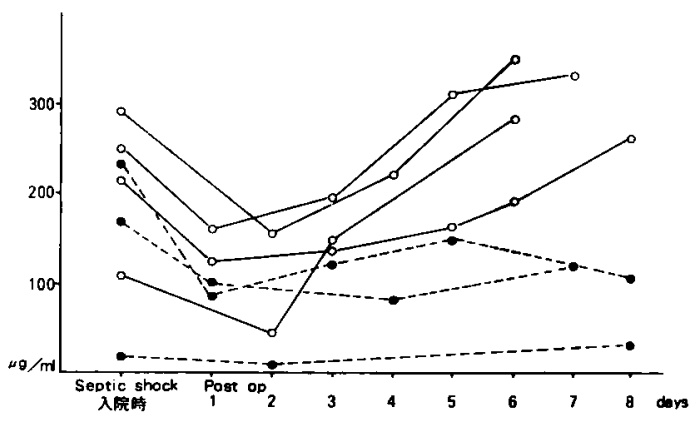

図 2 Plasma Fibronectin の推移（手術による影裂） ○一一 End (一) となり経過良好群 -..... MOF Patient

ナージ手術によりリムルステスト（一）となり，経過 良好例では血清 fibronectin 值は上昇を認めており，そ れと対照的に MOF 入移行した症例で住低值傾向を続 けその 2 例を失なった. 尚, 昭和59年以降の前述の二 期的手術を施行したリムルステスト $(+)$ 症例 4 例の 5ち，3 例は fibronectin 上昇例であり，治療に難浩し た症例 1 は fibronectin 持続低下例であった。

\section{Endotoxin 血症時における腸管の組織血流 についての実験的検討（図 3，4）}

雑種成犬 (平均体重 $7.5 \mathrm{~kg}$ ) 各 4 頭を用い, $25 \mathrm{mg} / \mathrm{kg}$ $の$ pentobarbital sodium 麻酔下に気管内挿管し, レス ビレーター（ハーバートモデル613）に接続，調節呼吸 を行なった，実験モデルは腹腔内横隔膜下面中央に endotoxin (E. coli $055 \mathrm{~B}_{5}$ Lipopolysaccharide Difco) $0.5 \mathrm{mg} / \mathrm{kg}$ を投与して作製した。 また腹腔内同部に生 食 $20 \mathrm{ml}$ を投与したるのを対照とした。腸管の組織血流 值は水素クリアランス式組織血流計")(ユニークメ ディカル社，MHG-Dl）を用い，小腸結膜下層にワィ 型（ユニークメディカル社，UHE-201）の白金電傮 を挿入した後，腸管を腹腔内にもどし，自然位とし， 

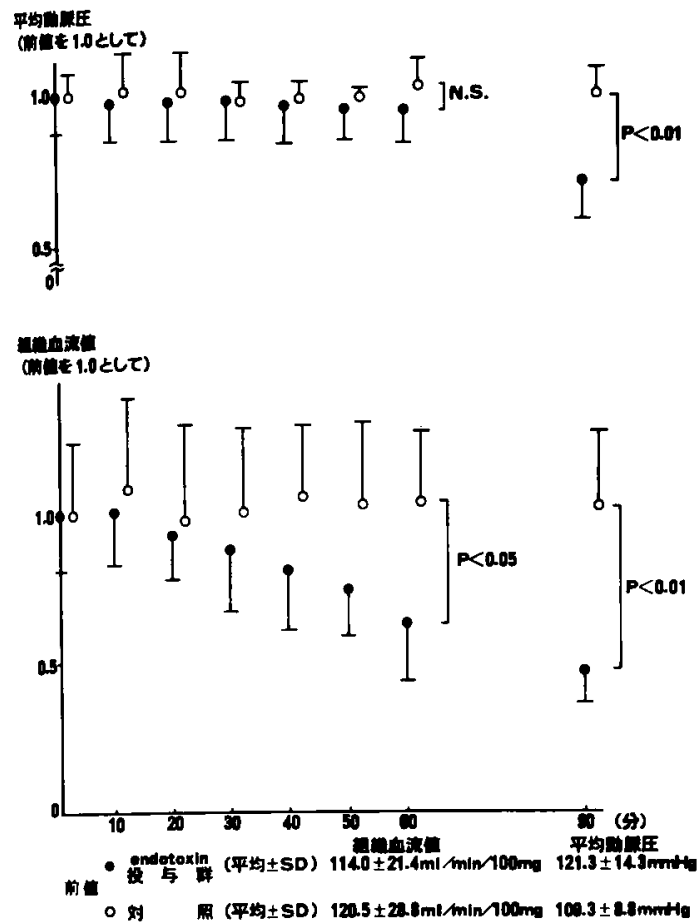

図 3 雑種成犬における腹肤内 endotoxin 投与実験 での腸管の組䋐血流値と平均動脈圧の変化

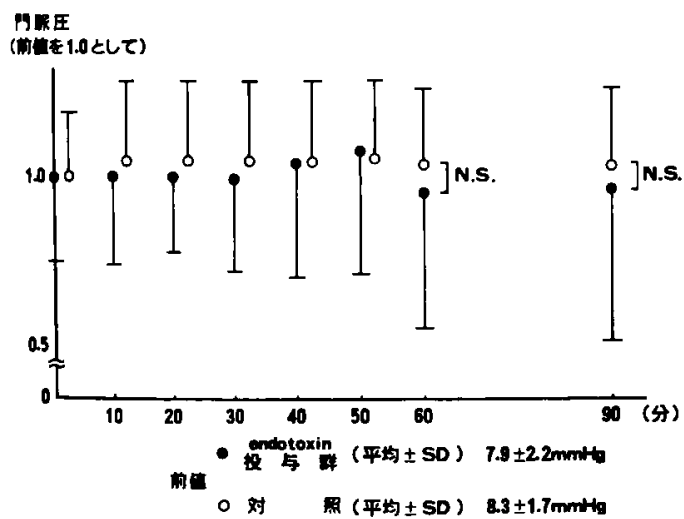

图4 赫種成犬における腹腔内 endotoxin 投与実験 での門脈圧の変化

匴壁の閉銷を完全に行い，組織血流值が安定するのを 待ち测定を開始した。平均動脈圧測定は大駺動脈に力 テーテルを留置して行ない, また門脈圧は脾静脈枝か ら門脈にカテーテルを挿入し，湘定した． Endotoxin の定量性発色合成基質法 ${ }^{21}$ とよる Toxicolor test(生化 学工萧)を用いて行なった。

この実験モデルで，動脈圧の低下を認めなかった endotoxin 投与後 1 時間以内において，小腸の組織血 流値を比較した。対照群では時間経過と共に変化は認 められなかったが, endotoxin 投与群では腸管の組織 血流值は endotoxin 投与後60分で投与前の114.0土 $21.4 \mathrm{ml} / \mathrm{min} / 100 \mathrm{~g}$ (平均士標準偏差) から71.7 \pm 22.2 $\mathrm{ml} / \mathrm{min} / 100 \mathrm{~g}$ と减少を認め, 対照群と有意差を認めた ( $p<0.05)$. その間の末梢血中 endotoxin 港度は，投与 前6.1土1.3pg/ml, 30 分後 $41.8 \pm 24.4 \mathrm{pg} / \mathrm{ml}, 60$ 分後 $560.1 \pm 238.6 \mathrm{pg} / \mathrm{ml}$ と漸増していた. 尚, endotoxin 投 与後90分において平均動脈王は対炤群に比し有意の低 下を認めた（p<0.01）。

また門脈圧に関しては，图4亿示す如く，全経過を 通しこの実験モデルでは有意の上昇を認めなかった。

\section{考察}

我々は昭和59年以前に 2 例の全身性エリテマトーデ ス（以下 SLE）に合併した小腸穿孔例に対し，小腸切 除後一期的吻合を行なったか，2 例とす縫合不全を来 たし MOF へ移行し，その 1 例を失なっだ!. その反省 から以下の如き敗血症性ショック時における手術術式 についての問題点を提示し検討を行なった，第一に， 敗血症性ショック時には一期的吻合でよいのか，また は腸瘦造設による二期的手術を選択すべきかといら問 題で, 二期的手術の根越として, 前述の SLE 症例の如 くこのような状況下では繾合不全の可能性が高いの ではないかといら事，さらに一旦䋖合不全を起こした 場合，そのコントロール，即ち感染巣の限局化は難し く，MOF 一移行し致命的になるのではないかといら 点を举げた．第二に敗血症性ショック時における手術 侵襲が病態に及ぼす影響について考えた。

まず䋖合不全の可能性についての検討であるが，敗 血症性ショック時には endotoxin 血症を併発してい る事が多ぐ，常にその病態を考える上で endotoxin の関与を念頭にいれておく必要がある.そこで，恽合 不全の発生は腸管の血流に影響を受けることに注目 し，実鈳的に雑種成犬を用い, endotoxin 血症時におけ る腸管の組織血流值を水素クリフランス法"1にて測定 した.この実験から, endotoxin 血症時には, 血王が維 持された状態であっても腸管の組織血流值は減少して おり，そのため䋖合不全の可能性が高いと考えた。こ の腸管組織血流の城少の機序としては, endotoxin 静 注時には hepatic venule やそれ以下の細小静脈が収 維することにより (post sinusoidal block)，門脈圧の 上昇を起こず)とされており，それによる腸管壁や腸 間静脈采のうっ滞6が原因と考えられ，実際にMa. 
cLean $5^{71}$ は endotoxin 静注後 3 分以内に腸管重量が $28 \mathrm{~g}$ から $170 \mathrm{~g}$ に増加したと報告している。しかし、こ れらの実験はいずれも2 3mg/ $\mathrm{kg}$ の endotoxin を静 注して作製しており, それに比し, 少量の endotoxin が緩徐に血中に移行する。より実地臨床の病態に即し た我々の endotoxin $0.5 \mathrm{mg} / \mathrm{kg}$ 腹腔内投与実験では門 脈圧の上昇を認めず，腸管組織血流の低下は門脈系の らっ滞では説明出来なかった。ここで, この実験モデ ルと同一のモデルにおいて測定した胸管リンパ流量の

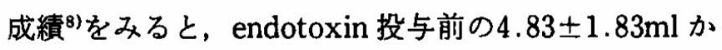
ら 2 時間目に $7.18 \pm 3.93 \mathrm{ml}(\mathrm{n}=6)$ と增加を認めて拉 り, 肝リンパと共に胸管リンパのほとんどを占める腸 管リンパ6)の增加が推察された，以上のことより, endotoxin 血症時における腸管組織血流値の悪化に腸管 自体の血管透過性の亢進が何らかの関与をしているの ではないかと推察した。

ここで, 動物の種による endotoxin に対する反応の 差す当然考虑されなければならない。この度, 実験動 物として使用したイヌにおいては，門脈系の血液の らっ滞が強く，一方ネコにおては高度の肺浮腫が前 面に出てくるといわれている9!。のよらにヒトと動 物との相達を認識しながらも，この実験は, ヒトに招 ける endotoxin 血症時の病態の一面を程度の差はあ るが, 特徽づけるものと考えている.

写真 1 は症例 2 における腸間膜内の小動脈の病理組 織像であるが, , 細小血管に拈ける内腔の狭窄や閉塞を 認め, 白血球の浸潤ならびにフィブリノイド変性を認 めている.このよ5に SLEやPNなどの膠原病にみ られる腸間膜血管における血管资を病因とした症例 は，小腸穿孔例の中では稀ではなく，またその潰瘍や 穿孔部は腸間膜付着部反対側という特徵があり ${ }^{10)}$, そ のような症例では血管炎による腸管の血流低下がさら に加味される事を考㦄する必要がある。

次に，一旦繾合不全を起こした場合における予後に ついての検討を行なった. 補体 $\mathrm{C}_{3} \mathrm{C}$ の敗血症性ショッ ク時に拐ける変化については過去報告したが少、ここ ではオブンニン蛋白である血清 fibronectin の推移に 注目した， $\mathrm{C}_{3} \mathrm{c}$ と同様に敗血症性ショック時において は，すでに低值を示寸症例が多く，さらに手術侵襲が 加わる事により減少を認めた。抢そらくその減少は消 費によるものと思われるが, このよらな補体や血清 fibronectin が低下した患者に縫合不全が発生したら, その新たな感染に対してすでに生体は対処する力を有 しておらす，MOFへ移行する可能性も高く, 致命的に

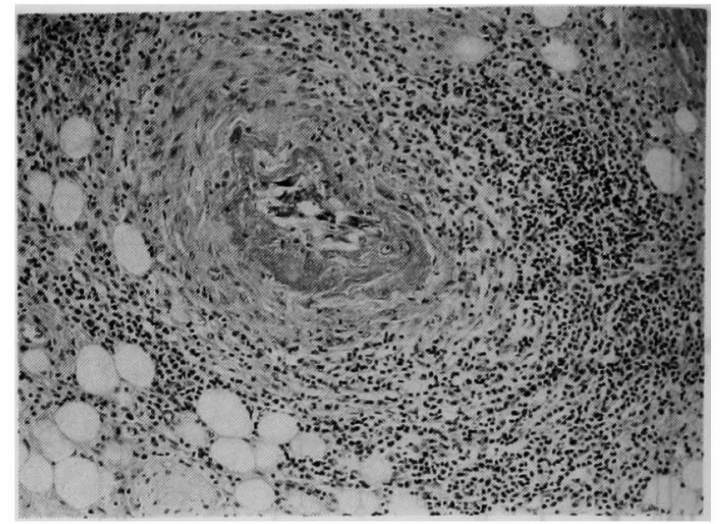

写真 1 PN における腸間膜内の小動脈の中核大像. 中膜のフィプリノィド变性, 外膜における多核白血 球，好酸球，リン八球，単球の漫潤を認める(H-E 染 色)

なると考えた。

以上の 2 点から, 我々は敗血症性ショック時におけけ る重症腹膜炎に対する手術術式は, 腸瘦造設による二 期的手術を原則として，昭和59年以降治療を行なって きた。しかし，ここで問題として残る事は, 敗血症性 ショック時に怙ける手術侵襲が病態に及ぼす影響につ いてである. 症例 1 では腹腔内の感染巢をドレナーシ したにもかかわらず, endotoxin 血庭は (土)から(十) へと悪化を認めている。これは腹腔内感染巣からの endotoxin 供給の增加よりもむしろ, 過度の手術侵褧 による生体における endotoxin clearance の障害が問 題ではないかと考えた。手術侵襲の指標として, 術中 出血量と手術時間をみたが，このような poor riskの 症例では手術侵襲をなるべく少なくするべく努める事 はいらまですないが，敗血症性ショックを起こすよう な腹膜炎症例は平均 6.2 日 と穿孔後長時間経過した症 例がほとんどで, 瘾着も著しく, いわゆる沉発性腹膜 炎といらよりむむしろ多発性の膿瘍のドレナージと いった方がよいような事が多く、完全なドレナージを 行ならためには, 全腸管を $1 つ 1 つ$ 剩離する必要があ り, 術中出血量ならびに手術時間に㧍いても相当の侵 醅を加えざるを得なかった。このため腹腔内における 感染巣の除去が行なわれても全身的な endotoxin 血 症をさらに悪化させるような症例が出たと考える、し かし不完全なドレナージで手術を終了する事には反対 であり,この点が今後の課題になると考える.最後に, この手術侵襲の面からも，腸管の吻合に時間を費やす より，限られた手術時間をドレナージにできるだけ使 
用し，腸瘦造設を行い，二期的に吻合を行ら方がより 合理的と考える.

$$
\text { 結語 }
$$

1) 最近 3 年間に 6 例の敗血症性ショックを併発し た重症腹膜炎症例に対し，以下の点に留意して手術施 行したので報告した。

2）敗血症性ショック時における腸管では, 縫合不全 の可能性が高く，また一旦合併すれば致命的となる事 か，実検的ならびに臨床データより推察されたため， このよらな状況下では一期吻合を避け，腸瘦造設によ る二期的手術を選択した.

3）敗血症性ショック症例で，とくに手術侵襲が病態 に及注す影響について考慮された術式を選択すべきで ある。

$$
\text { 文嗝 }
$$

1）重松 去，场江良枝，佐藤正典他：腸管壁の局所血 流測定について一水素ガスクリアランス法を中心 として一, 日消誌 $78: 846-855,1981$

2）大林民典, 河合 忠：血中エンドトキンンの定量， 消外 $6: 595-599,1983$

3）檜山英三, 市川徹, 横山隆：小児に合併した小 腸穿孔の 2 症例, 日小外会誌 $20: 1239-1246$, 1984

4）竹末芳生，横山 隆, 三好信和他：Septic shock 症 例の検討一とくに endotoxin 血症と MOF, DIC の関連について一, 日臨外会誌 $46: 1531-1536$,
1985

5) Chein S, Sinclair DC, Dellenback RJ : Effect of endotoxin on capillary permeability to ma. cromolecules. Am J Physiol 207 : 518-522, 1964

6) 細江志郎：実験的エンドトキシンショックにおけ る晹管リンパ反応一とくに肝リンハ，腸リンパ の関与を中心に一, 信州医誌 $30: 22-38,1982$

7) MacLean LD, Weil MH, Spink WW : Canine intestinal and liver weight changes induced by E. coli endotoxin. Proc Soc Exp Biol Med 92 : 602-605, 1956

8）竹末芳生：腹膜炎におけるエンドトキシン血症発 生に関する研究一とくにェンドトキシン吸収につ いての検討，日外会誌 $88: 327-339,1987$

9）元木良一：全身感染症, sepsis, エンドトキシン血 症, 救急医 $10: 1249-1256,1986$

10）溴根一郎，板合英世，田浦晴也他：腸壁壊死, 出血, 溃慯形成および穿孔など多彩な腸病变を呈した結 節性動脈周囲炎 (PN)の 1 例，胃之腸 $10: 1525$ $-1530,1975$

11) Yokoyama $T$, Miyoshi $N$, Kodama $T$, et al: Studies on multiple organ failure and plasma fibronectin, serum complement $\left(\mathrm{C}_{3}\right)$ levels and associated variables in surgical septic shock patients. Hiroshima J Anesthesia 20: 91-99, 1984

\title{
STUDIES ON OPERATIVE PROCEDURES FOR SERIOUS PERITONITIS CASES WITH SEPTIC SHOCK
}

\author{
Yoshio TAKESUE, Takashi YOKOYAMA, Hiroshi YAMADA, \\ Takashi KODAMA and Mikio FUJIMOTO \\ First Department of Surgery, Hiroshima University School of Medicine
}

Over the past three years we have carried out biphasic surgery involving enterostomy for six patients with serious peritonitis associated with septic shock. The first reason for carrying out this form of surgery was that the blood flow volume of the intestinal tissues was decreased from $114.0 \pm 21.4 \mathrm{ml} / \mathrm{min} / \mathrm{kg}$ to $71.7 \pm 22.2 \mathrm{ml} / \mathrm{min} / \mathrm{kg}$ within one hour even under conditions of sustained blood pressure, as revealed by the hydrogen clearance method in experiments employing intraperitoneal administration of endotoxin, suggesting a significant difference $(\mathrm{p}<0.05)$ between the endotoxin group and a control group. From the results obtained, it was considered highly likely that leakage from the anastomosis would occur in endotoxemia. The second reason was that most of the patients showed low levels of serum fibronectin and complement $\left(\mathrm{C}_{3 \mathrm{c}}\right)$ during septic shock, which would have been further decreased by surgical stress. If leakage from the anastomosis were to occur under such conditions, the result in a living body would be fatal, since the body's resistance would already be expended. In patients with septic shock, surgical stress occasionally exceeds the level intended for the complete drainage of an intraperitoneally infected lesion, possibly inducing exacerbation of the postoperative state of a patinet. This point seems to be worthy of further investigation. 